\title{
The Impact of Public Debt on the Economic Growth of Jordan: An Empirical Study (2000-2015)
}

\author{
Tawfiq Ahmad Mousa ${ }^{1} \&$ Abdullah M Shawawreh ${ }^{1}$ \\ ${ }^{1}$ Assistant Professor, Faculty of Economics and Administrative Sciences, Al- Zaytooneh University, Amman, Jordan \\ Correspondence: Tawfiq Ahmad Mousa, Assistant Professor, Faculty of Economics and Administrative Sciences, \\ Al- Zaytooneh University, Amman, Jordan
}

Received: March 8, 2016

Accepted: March 27, 2017

Online Published: April 1, 2017

doi:10.5430/afr.v6n2p114

URL: https://doi.org/10.5430/afr.v6n2p114

\begin{abstract}
In the last two decades, Jordan's economy has been relied on public debt in order to enhance the economic growth. As such, an understanding of the dynamics between public debt and economic growth is very important in addressing the obstacles to economic growth. The study investigates the impact of public debt on economic growth using data from 2000 to 2015. The study employs least squares method and regression model to capture the impact of public debt on economic growth. The results of the analysis indicate that there is a negative impact of total public debt, especially the external debt on economic growth.
\end{abstract}

Keywords: Public debt, Gross domestic product, External debt, External debt service

\section{Introduction}

Jordan is a smaller and lower- middle income country, with limited resources and dependent on workers remittances and foreign aid. The development process of the Jordanian economy during the past decades had resulted in high growth rates of GDP and significant progress in social and economic fields. This success of high economic growth lasted up to the mid of the 1980's, when the boom in oil prices came to an end and the Jordan's macroeconomic imbalances began to be more clear and peaked in 1989.

Jordan started a prudent economic adjustment programme under the patronage of IMF to sustain the economic stability and to face many challenges that hit the economy, such as; high budget deficit, chronic trade deficit, high rate of poverty and unemployment in addition to the high rate of population growth.

In the last decade, the economy of Jordan was severely affected by what is called (Arab Spring), increase of oil prices, international financial crisis and the influx of Syrian refugees. All these factors led the government to rely more on external and internal debts.

Public debt, be it external or internal is considered as a source of financing that the government depends on to realise its economic and social objectives, especially when there is a gap between savings and investments and foreign currencies needed.

Despite the fact that the economic theories do not state the effect of public debt on economic growth explicitly, some theories suggest that a reasonable level of public debt is acceptable to enhance economic growth (Pattillo, Ricci, and Porison 2002) provided that this debt is utilized in productive investments with rates of return higher than the interest rates of borrowed funds; otherwise a risk of default is more likely to take place.

\section{Statement of the Problem}

During the last two decades, Jordan heavily relied on public debt in order to accelerate the economic development, but on the contrast and due to above-mentioned reasons the economic growth is still staggering and the public debt has gone beyond acceptable levels. The public debt has increased from 5987.billion dinars in 2000 to 22847 billion which amounts to $85.9 \%$ of GDP.

In order to reduce the burden of debt and to face all the economic challenges, Jordan opted to be a part of the "international economy "through adopting principles of economic liberalization. 


\section{Objective of the Study}

The aim of this study is to examine the impact of public debt and debt service on the economic growth of Jordan during the period 2000-2015, through statistical and economic methods.

The study is based on descriptive analysis of public debt in terms of its development and its impact on economic growth of Jordan, in addition to statistical analysis by using least squares method to find the nature of the relationship between the variables. The study objectives can be summarized as follows:

1. To investigate the impact of external debt on gross domestic product.

2. To investigate the impact of domestic debt on gross domestic product

3. To investigate the impact of debt service on gross domestic product.

4. To investigate the impact of public debt on gross domestic product.

\section{Literature Review}

There are many studies that investigated the impact of public debt on economic growth. The academic research on this subject has intensified after the debt crisis that hit many developing countries in the 1980's. However, many empirical studies have been conducted in the last years to assess the impact of external debt on economic growth but the results were different.

Al-Refai (2005) investigated the relationship between debt and economic growth in Jordan for the period (1990-2013) using Cobb- Douglas production function. The results showed a negative relationship between external debt and economic growth.

Babu et al. (2014) examined the impact of external debt on the economic growth in the East African Community during the period (1970-2010). Using Johansen-co-integration test. The results indicated a negative impact of external debt on the economic growth in the East Africa Community.

Ahmed et al. (2015) examined the impact of external debt on economic growth in Iraq during the period (1980-2014) using autoregressive distributed lag. The results showed a negative impact of external debt on gross domestic product (GDP) especially in the short-run.

Greiner (2011) argued that the effect of debt on growth depends on the presence of rigidities in the economy. In a model with no rigidities and elastic labour supply, public debt has a negative effect on labor supply, investment and economic growth. In the presence of wage rigidities and unemployment, public debt has no effect on the allocation of resources and can have a positive effect on growth if it is used to finance productive investment.

Reinhart and Rogoff (2010) studied the relationship between high public debt, growth and inflation in 44 countries using a panel framework. They found that a ratio of public debt to GDP in excess of 90 percent has a negative impact on economic growth.

Atique and Malik (2012) examined the impact of domestic debt and external debt on the economic growth in Pakistan during the period (1980-2010) using a least square approach based on co-integration, unit root and serial correlation testing. The results showed a negative impact of public debt on the economic growth.

Bader and Magableh (2009) examined the determinants of Public Debt in Jordan, using Johansen co-integration Test for the period (1980-2004). The study found that the saving gap, budget deficit, real exchange rate and flow of foreign aid were the main determinants of public debt.

Ahmed et al (2015) investigated the impact of external debt on economic growth in Iraq during the period (1980-2014) using ARDL through OLS autoregressive distributed lag. The results showed a negative impact of external debt on GDP in the short-run as well as in the long-run.

Boboye and Ojo (2012) studied the effect of external debt on economic growth in Nigeria. Ordinary least square multiple regression technique was used. The findings indicated a negative effect of external debt on the nation's income and per capita income.

Karagol (2002) examined the relationship between economic growth and external debt service for Turkey for the period 1956-1996. The author used multivariate co-integration techniques. The study showed a negative relationship between external debt and economic growth in the long -run.

In addition to public debt, there are several other factors that can impact the economic growth of a country. Including but not limited to globalization and integration into global markets (Riasi \& Amiri Aghdaie, 2013), foreign direct investment (Borensztein et al., 1998) and human capital (Benhabib \& Spiegel, 1994)” 


\section{Methodology, Analysis and Results}

The study covers the period from 2000 to 2015. Annual data were collected from secondary sources, such as, the Statistical Bulletins of the Ministry of Finance, Statistical Bulletins of the Central Bank of Jordan and Department of Statistics.

Table 1. Indicators of Public Debt for the period (2000-2015)

In million dinars

\begin{tabular}{lllllll}
\hline Year & $\begin{array}{l}\text { External } \\
\text { Debt }\end{array}$ & $\begin{array}{l}\text { Domestic } \\
\text { Debt }\end{array}$ & $\begin{array}{l}\text { Total Public } \\
\text { Debt }\end{array}$ & $\begin{array}{l}\text { Gross Domestic } \\
\text { Product }\end{array}$ & $\begin{array}{l}\text { Public Debt \% } \\
\text { of GDP }\end{array}$ & $\begin{array}{l}\text { Public Debt per } \\
\text { capita in JD }\end{array}$ \\
\hline 2000 & 5043.5 & 944 & 5987.5 & 5996.5 & 99.8 & 980 \\
2001 & 4969.8 & 1218 & 6187.8 & 6082.9 & 101.7 & 973 \\
2002 & 5350.4 & 1335 & 6685.4 & 6781.2 & 98.6 & 1,318 \\
2003 & 5391.8 & 1704 & 7095.8 & 7208.3 & 98.4 & 1,365 \\
2004 & 5348.8 & 1843 & 7191.8 & 8166.1 & 88.1 & 1,343 \\
2005 & 5056.6 & 2437 & 7493.6 & 9595.1 & 78.1 & 1,369 \\
2006 & 5186.5 & 2163 & 7349.5 & 10671.8 & 68.8 & 1,312 \\
2007 & 5253.3 & 2946 & 8199.3 & 12132.3 & 67.6 & 1,433 \\
2008 & 3640.2 & 4911 & 8551.2 & 15623.2 & 54.5 & 1,462 \\
2009 & 3869.0 & 5791 & 9660.0 & 16895.2 & 57.2 & 1,615 \\
2010 & 4610.8 & 6852 & 11462.8 & 18743.1 & 61.1 & 1,875 \\
2011 & 4486.8 & 8915 & 13401.8 & 20487.7 & 65.4 & 2,145 \\
2012 & 4932.4 & 11648 & 16580.4 & 21921.8 & 75.6 & 2,590 \\
2013 & 7234.5 & 11863 & 19097.5 & 23.876 .2 & 79.9 & 2,902 \\
2014 & 8030.1 & 12525 & 20555.1 & 25411.7 & 80.9 & 3,077 \\
2015 & 9390.0 & 13475 & 22847.0 & 26600.5 & 85.9 & 3,184 \\
\hline
\end{tabular}

Source: Ministry of Finance / Jordan, Vol.14 No.5 June 2012. Vol.7.No.15 January 2005 and Vol. 18.No.11.January 2016.

From the Table 1, we can see that in the last decade, total public debt(external and domestic) increased from JD 7349.5 which constitutes $68.8 \%$ of GDP to JD 22847.0 which constitutes $85.9 \%$ of GDP. This increase in public debt heavily affected the growth of GDP in Jordan which decreased from $10.6 \%$ in 2007 to $2 \%$ in 2015.

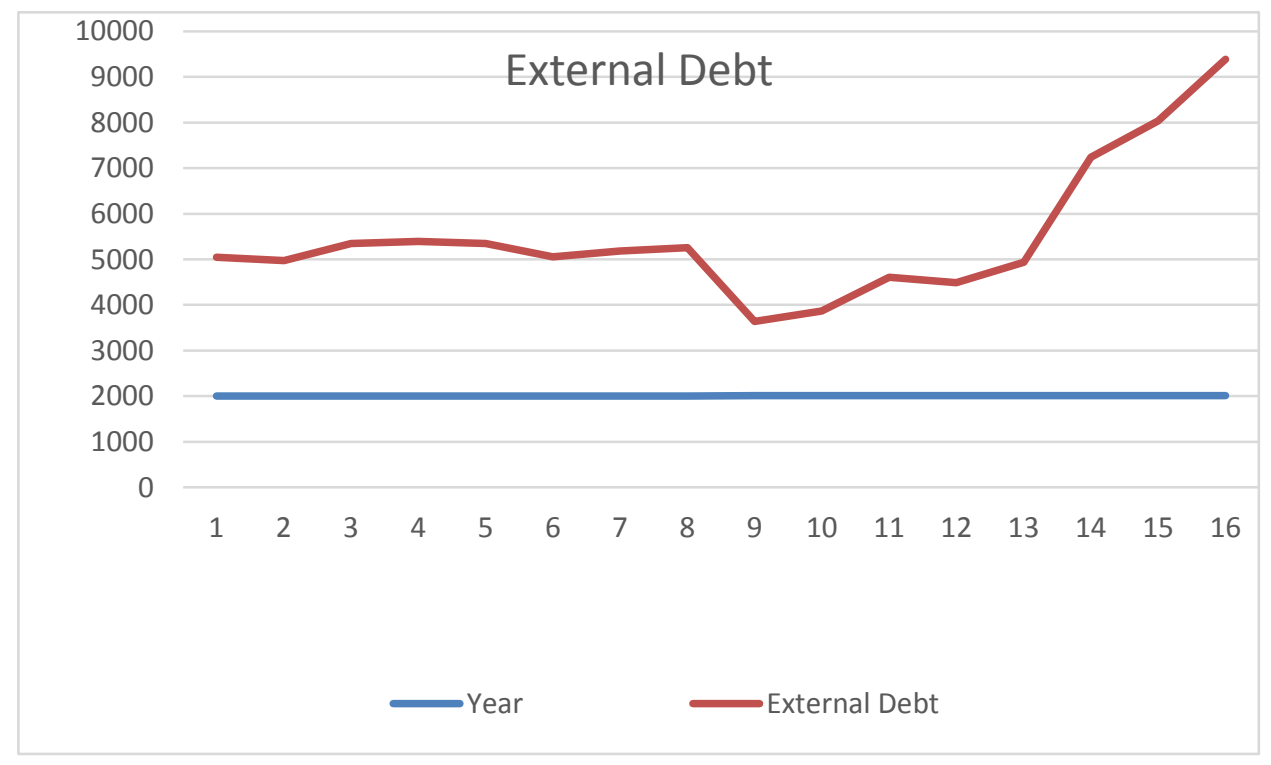



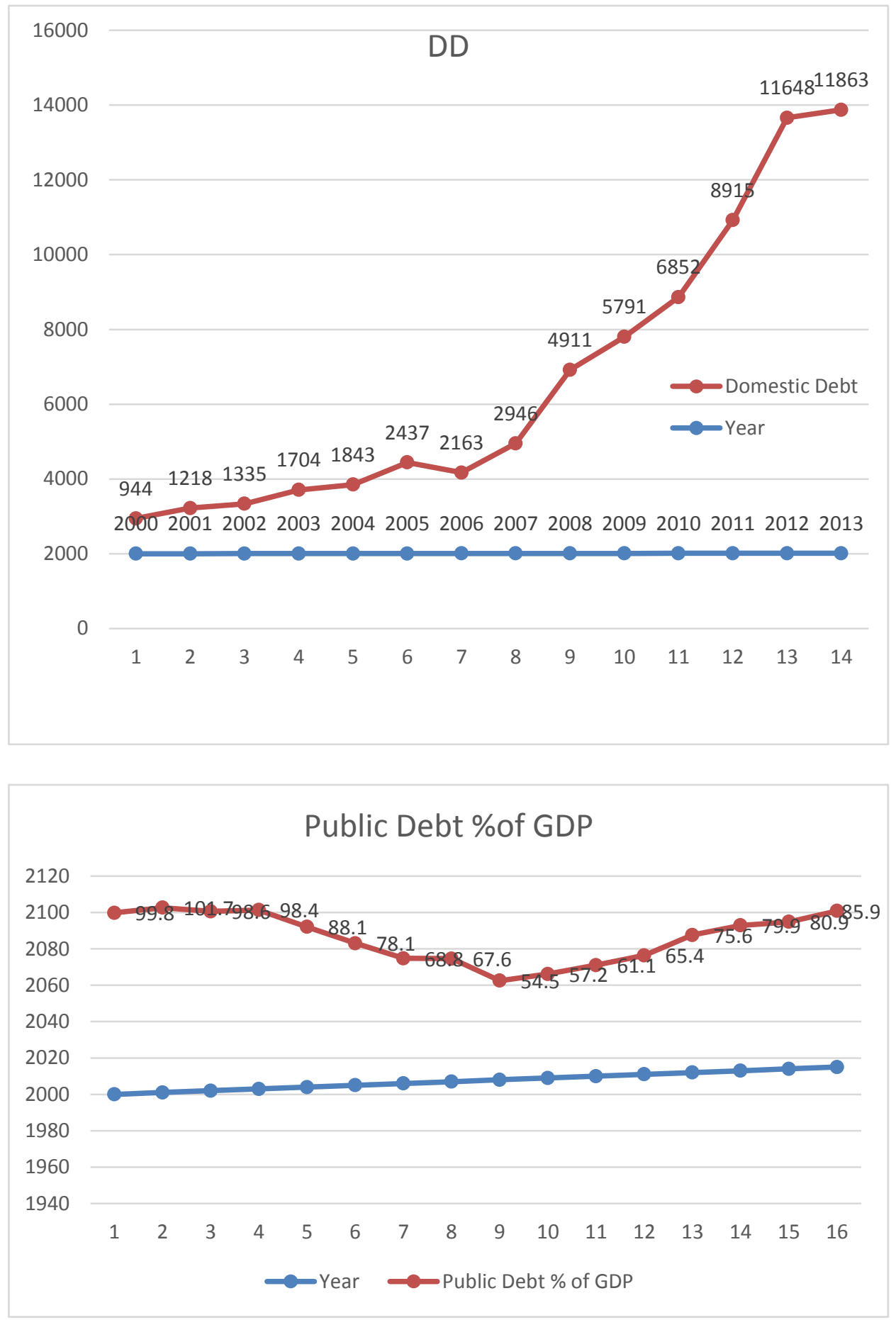
Table 2. Percentage growth of public debt compared to GDP growth

\begin{tabular}{llll}
\hline Year & $\begin{array}{l}\text { GDP Growth } \\
\text { In Current Prices }\end{array}$ & $\begin{array}{l}\text { Public } \\
\text { Growth }\end{array}$ & $\begin{array}{c}\text { Debt } \\
\text { Difference between Public Debt } \\
\text { and GDP Growth }\end{array}$ \\
\hline 2000 & - & - & \\
2001 & $1.4 \%$ & $3.3 \%$ & $1.9 \%$ \\
2002 & $11.1 \%$ & $8.0 \%$ & $-3.1 \%$ \\
2003 & $6.3 \%$ & $6.1 \%$ & $-0.2 \%$ \\
2004 & $17.4 \%$ & $1.3 \%$ & $-16.1 \%$ \\
2005 & $11.2 \%$ & $4.2 \%$ & $-7 \%$ \\
2006 & $13.6 \%$ & $-1.9 \%$ & $-15.5 \%$ \\
2007 & $13.7 \%$ & $11.6 \%$ & $-2.1 \%$ \\
2008 & $28.8 \%$ & $4.3 \%$ & $-24.5 \%$ \\
2009 & $8.1 \%$ & $12.9 \%$ & $4.8 \%$ \\
2010 & $10.9 \%$ & $18.7 \%$ & $7.8 \%$ \\
2011 & $9.3 \%$ & $16.9 \%$ & $7.6 \%$ \\
2012 & $7.0 \%$ & $23.7 \%$ & $16.7 \%$ \\
2013 & $8.9 \%$ & $18.1 \%$ & $9.2 \%$ \\
2014 & $6.4 \%$ & $7.6 \%$ & $1.2 \%$ \\
2015 & $4.7 \%$ & $11.1 \%$ & $6.4 \%$ \\
\hline
\end{tabular}

Source: Author's compilation based on Table 1.

From Table 2.we can notice that there is an inverse relationship between the growth of GDP and the growth of public debt. In addition, we can see that during the period of global financial crisis there is an evident decerease of GDP form $28.8 \%$ in 2008 to $4.7 \%$ in 2015, while the publich debt increased from $4.3 \%$ to 11.1 in 2015 .

Table 3. External Public Debt Service (Budget and Guaranteed)

In Million JD

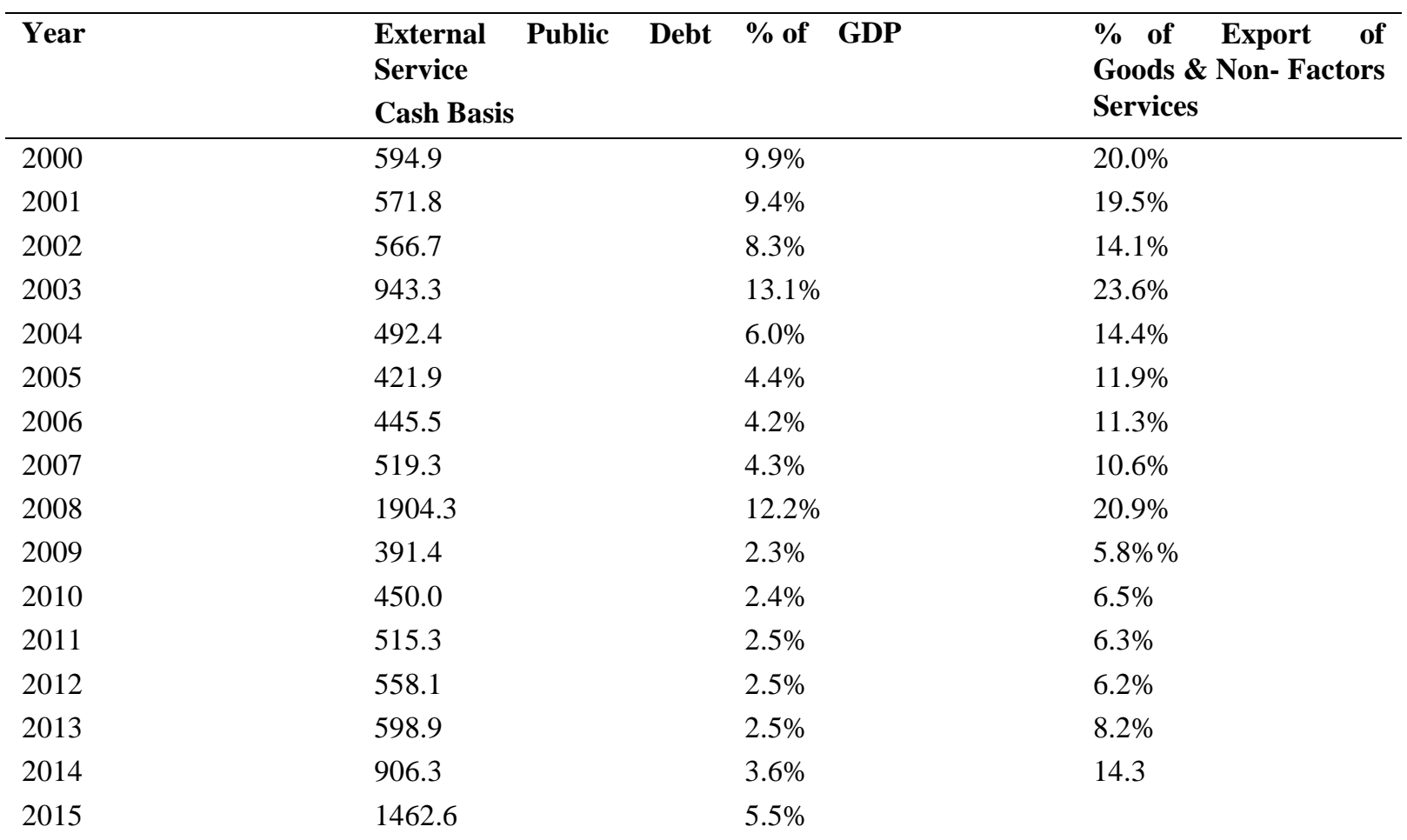

Source: Ministry of finance/ Jordan, and World Bank International Debt Statistics(1960-2015) ,http: // data worldbank org /s 
According to the above table, we can notic that during the last five years External Public Debt Service has increased form 515.3 to 1462.6 in 2015 which negatively affect the government budget.

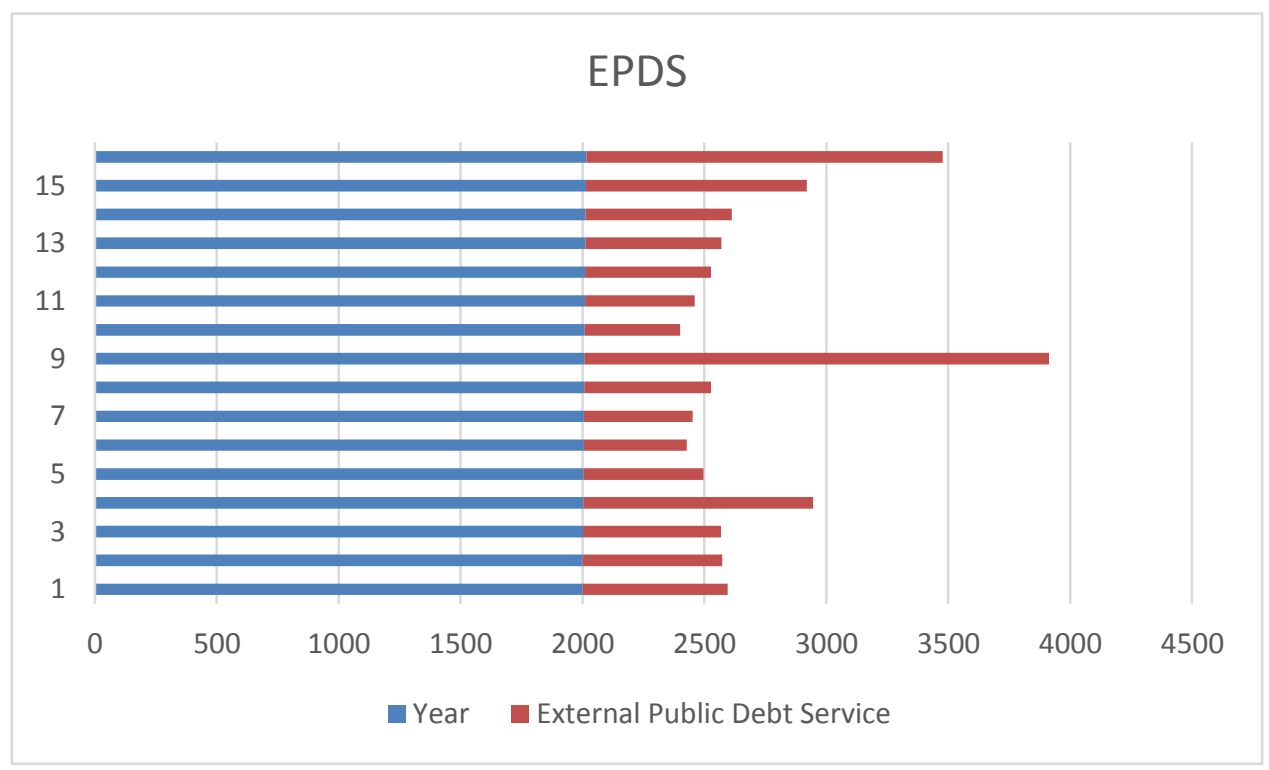

\section{Hypotheses Testing and Analysis}

$\begin{array}{lr}\text { Dependent } & \text { Variable: } \\ \text { GDP } & \\ \text { Method: } & \text { Least } \\ \text { Squares } & \end{array}$

\begin{tabular}{llll}
\hline Inedpendent & R-squared & F-statistic & Prob(F-statistic) \\
\hline DD & 0.957 & 290.626 & 0.000 \\
\hline ED & 0.218 & 3.630 & 0.079 \\
\hline EPDS & 0.109 & 1.582 & 0.231 \\
\hline TPD & 0.873 & 89.450 & 0.000
\end{tabular}

1. There is a negative statistical impact of external debt on GDP growth, where an increase in the external debt will lead to decrease in GDP growth.

2. There is a positive statistical impact of domestic debt on GDP growth, where an increase in the domestic debt will not lead to decrease in GDP growth. This due to the fact that the internal debt constitutes only a re -distribution of resources without causing any change in the total resources of the community, such as human and natural resources, in addition to capital formation.

3. There is a positive statistical impact of debt service on GDP growth.

4. There is a negative statistical impact of total public debt on GDP growth. Where an increase of total public debt will lead to decrease in GDP growth.I

\section{Conclusion}

This paper aimes at investating the impact of publich debt on the GDP growth in Jordan during the period of 2000-2015, The study employs least squares method and regression model to capture the impact of public debt on economic growth. The results of the analysis indicate that there is a negative impact of total public debt, especially the external debt on economic growth.

\section{Recommendations}

1. In the light of the study results, it is better to depend on the available internal resources than depending on external debt. 
2. It is important to analyze all other factors that affect the gross domestic product growth in order to determine the factors that have a positive impact on the economic growth.

\section{References}

Ahmed, Y., Saeed. S., \& Saed, S. (2015). The Impact of External Debt on Economic Growth : Empirical Evidence Iraq. International Journal of Science and Research, 4(8), 1506-1516.

Al-Refai. (2015). Debt and Economic Growth in Developing Countries: Jordan as a Study. International of Economics and Finance, 7(3),81-98. https://doi.org/10.5539/ijef.v7n3p134

Alshyab, N. (2016). Domestic versus External Public Debt in Jordan : An Empirical Investigation Jordan. Journal of Economic Sciences, 3(1), 81-98. https://doi.org/10.12816/0029858

Atique, R., \& Malik.K. (2012). Impact of Domestic and External Debt on the Economic Growth of Pakistan. World Applied Sciences Journal, 20(1), 120-129.

Babu.J., Symon.k., Aquilars.M., \& Mose G. External debt and economic growth in the east Africa Community. African Journal of Business Management, 8(21), 1011-1018.

Bader, M. \& Magableh,I. (2009). An Enquiry into the Main Determinants of Public Debt in Jordan: An Econometric Study, Dirasat. Administrative Sciences, 36(1).

Benhabib, J., \& Spiegel, M. M. (1994). The role of human capital in economic development evidence from aggregate

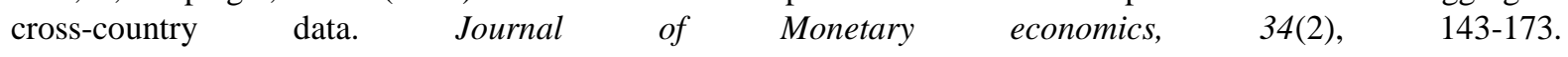
https://doi.org/10.1016/0304-3932(94)90047-7

Boboye,A., \& Ojo , O. (2012). Effect of External Debt on Economic Growth and Develpoment of Nigeria. International Journal of Business and Social Sciences, 3(12), 297-304.

Borensztein, E., De Gregorio, J., \& Lee, J. W. (1998). How does foreign direct investment affect economic growth? Journal of international Economics, 45(1), 115-135. https://doi.org/10.1016/S0022-1996(97)00033-0

Greiner,A. (2011). Economic Growth, Public Debt and Welfare: Comparing Three Budget Rules. German Economic Review ,12(2), 205-222. https://doi.org/10.1111/j.1468-0475.2010.00516.x

Hameed et al. (2008). External Debt and its Impact on economic and Business Growth in Pakistan. International Resesarch Journal of Finance and Economics ISSN 1450- 2887. Issue 20 (2008).

Karagol. (2002). The Causality Analysis of External Debt Service and GNP:The case of Turkey. Central Bank Rewiew, 85(5) 1106-17.

Karagol. (2002). The Causality Analysis of External Debt Service and GNP:The case of Turkey. Central Bank Rewiew, 85(5), 1106-17.

Malik et al. (2010). External Debt and Economic Growth: Empirical Evidence from Pakistan. International Resesarch Journal of Finance and Economics, ISSN 1450- 2887. Issue 20 (2008) Issue 44 (2010)

Patillo, C.,Poirson .H. \& Ricci. I. (2002). External Debt and Growth. IMF Working paper (http://www.imf.org).

Riasi, A., \& Amiri Aghdaie, S. F. (2013). Effects of a hypothetical Iranian accession to the world trade organization on Iran's flower industry. Consilience: The Journal of Sustainable Development, 10(1), 99-110.

World Bank International Debt Statistics. (1960-2015). http://data worldbank org/s. www.mof.gov.jo. http//www.mof.gov.jo 